\title{
Intellectual capital in non-profit organisations: lessons learnt for waqf institutions
}

\author{
Abdelkader Laallam, Salina Kassim and \\ Engku Rabiah Adawiah Engku Ali \\ Institute of Islamic Banking and Finance, International Islamic University \\ Malaysia, Kuala Lumpur, Malaysia, and \\ Buerhan Saiti \\ Department of Islamic Economics and Finance, Istanbul Sabahattin Zaim \\ Universitesi, Istanbul, Turkey
}

\begin{abstract}
Purpose - This study aims to highlight the importance of intellectual capital (IC) for the operation of waqf (Islamic endowment) institutions, as few studies have discussed this issue in relation to non-profit religious organisations, particularly waqf organisations. Consequently, this study hopes to contribute to the development of waqf institutions in terms of human capital proficiency, the efficiency of operations and the effectiveness and sustainability of performance.

Design/methodology/approach - The authors reviewed a significant body of relevant studies written on various aspects of IC, to highlight the significance of considering IC in the operation of non-profit organisations (NPOs) and waqf institutions.

Findings - This study highlights the importance of IC in the operation of waqf institutions. It provides a platform that facilitates understanding of the existing obstacles and challenges in waqf institutions (such as lack of accountability, lack of funding, mismanagement and lack of trained labour, among others) and offers potential solutions through the consideration of knowledge and IC.

Research limitations/implications - This study is a conceptual analysis of IC in the context of NPOs. Future studies should conduct empirical testing, which will provide more detailed discussion and enriching insights into the issue of IC and the performance of NPOs, particularly in the case of waqf institutions.

Practical implications - This study provides several important implications for waqf institutions and other NPOs, as it sheds light on the consideration of knowledge and IC in their operations.

Originality/value - To the best of the authors' knowledge, this study is the first to discuss the issues of waqf in the light of IC and provide an integrated framework for the operation of waqf institutions.
\end{abstract}

Keywords Organisational performance, Intellectual capital, Islamic finance,

Non-profit organisations, Waqf institutions

Paper type Conceptual paper

(C) Abdelkader Laallam, Salina Kassim, Engku Rabiah Adawiah Engku Ali and Buerhan Saiti. Published in ISRA International Journal of Islamic Finance. Published by Emerald Publishing Limited. This article is published under the Creative Commons Attribution (CC BY 4.0) licence. Anyone may reproduce, distribute, translate and create derivative works of this article (for both commercial and non-commercial purposes), subject to full attribution to the original publication and authors. The full terms of this licence may be seen at http://creativecommons.org/licences/by/4.0/ legalcode

We acknowledge the support provided from Kuwait Awqaf Public Foundation in conducting this research. Received 9 October 2018
Revised 23 December 2018
5 May 2019
28 November 2019
28 February 2020
Accepted 28 February 2020 
IJIF

12,1

28

\section{Introduction}

The growth of the knowledge-based economy ("k-economy") has resulted in a rapid transformation of current business practices, resulting in knowledge-based resources becoming a vital factor in determining and shaping the wealth and sustainability of organisations. An important component of the k-economy, namely, intellectual capital (IC), has become a contributing factor in the development and enhancement of competitiveness, whether an organisation is profit-seeking or non-profit (Mustapha and Abdullah, 2004). IC is a broad concept that considers knowledge and learning abilities (Cohen and Vlismas, 2013), as well as skills available within the organisation, to be the key factors in economic development - rather than focussing solely on physical and other resources (Mustapha and Abdullah, 2004).

To date, only a limited number of studies have explored the role of IC in enhancing the performance and effectiveness of religious institutions such as zakat (alms), waqf (Islamic endowment) institutions and other non-profit organisations (NPOs). Waqf institutions are best understood as NPOs that are responsible for managing endowment funds and properties in Muslim countries (Adnan et al., 2013). Studies assessing waqf institutions commonly highlight two areas of concern, namely,

(1) the ineffectiveness of waqf properties in many aspects; and

(2) the insufficiency of available information regarding waqf (Sulaiman and Zakari, 2015).

This is reflected in the absence of a waqf governance system, as well as the general disregard for knowledge management and IC in these institutions (Hashim et al., 2018). The existence of IC is, therefore, critical to waqf institutions and NPOs, as IC involves intangible assets that contain knowledge and can help these institutions to accomplish their goals, thereby increasing their efficiency and effectiveness (Adnan et al., 2013).

This study aims to highlight the importance of IC in the operations of waqf institutions and NPOs, as few studies have discussed this issue in relation to non-profit religious organisations, particularly waqf organisations. Consequently, the study hopes to contribute to the development of NPOs, particularly waqf institutions, in terms of human capital (HC) proficiency, the efficiency of operations and effectiveness and sustainability of performance.

The remaining parts of this paper are organised as follows:

- the second section represents a literature review;

- under which fall both the concept and classification of NPOs; and

- in which the importance of IC in NPOs is discussed.

The third section proposes a conceptual framework of IC in NPOs, along with a review of IC application in the context of certain NPOs. The fourth section concentrates mainly on the issues of current waqf management and its potential for reform through the consideration of IC. The final section provides a summary of the paper's main points and draws lessons and implications from which waqf institutions can learn.

\section{Literature review}

The concept and classification of non-profit organisations

The term "non-profit" refers to any organisation in which owners or partners are not entitled to any share in the profits (Hansmann, 1979; Steinberg and Gray, 1993; Salamon and Anheier, 1997). They have no intention of making a profit, although these organisations may generate income in the fiscal year (Salamon and Anheier, 1997). The non-profit sector aims 
at promoting some non-monetary value, with no use of coercive power, by creating NPOs that neither provide returns to investors nor to a group of individual owners or shareholders (Considine, 2003). Although they are called NPOs, they often have a surplus of income on expenditure, resulting in profit (Weisbrod, 2009). Therefore, the term "profit" is clearly defined according to its technical meaning in accounting and not according to its meaning in the general society (Haji-Mohiddin and Mas, 2015).

Based on the international classification of NPOs (ICNPO), endorsed by the NPOs handbook (Salamon and Anheier, 1996), NPOs are divided into 11 major groups. These groups are further subdivided into 24 subgroups, which include the following sectors: "culture and recreation", "education and research", "health", "social services", "environment", "religion", "business and professional associations, unions", etc. The features of the 11 groups of NPOs classified by the ICNPO vary widely with regard to their mission profile, the nature of services provided, the target users in the society and the delivery of their products.

For NPOs' operations, the human and social aspects are considered to be as important as the financial aspects or even more. This is because of the NPOs' mission, which is the delivery of services - where maintaining contact with an organisation's target users is crucial. Therefore, the job performed by human resources, especially in terms of their abilities, skills and proficiencies in dealing with people and other staff and members, is pivotal in such a working environment (Bronzetti et al., 2011). Establishing a communication channel, which connects both external and internal stakeholders is crucial in NPOs because it helps mediate between their differing expectations. Two essential keys to the successful implementation of this communication channel are personnel empowerment and capitalising on the organisational culture (Kong, 2007). The clear importance of IC as a crucial area of study is what motivated this research.

\section{The concept and classifications of intellectual capital}

IC represents the stock of available knowledge within an organisation at a specific time because of the accumulation of knowledge flow $\left.{ }^{1}\right]$ activities (Seleim and Khalil, 2007; Khosla et al., 2010; Shih et al., 2010; Seleim and Khalil, 2011; Kianto et al., 2014). Others define IC as specific combinations or groupings of knowledge that reflect intangible values within an organisation (Freeburg, 2016). Previous research on IC classification aimed to split IC into different components. One of the first attempts at classification was the Sveiby (1997) framework, which is regarded as one of the most popular classification frameworks in IC literature. Sveiby (1997) categorises IC into three components as follows: internal structure, external structure and employee competence.

Another classification framework, proposed by Edvinsson and Malone (1997), categorised IC into two elements as follows: structural capital (SC), which encompasses organisational and customer capital, and HC. Nonetheless, Stewart and Ruckdeschel's (1998) classification is most commonly used in IC literature, where IC is divided into three elements, namely, human, structural and relational capital (RC). However, this does not indicate that only these classifications can be considered among the elements of IC, as some scholars classified IC as having more than three elements (Khalique et al., 2013; Khalique et al., 2015). Most of the previous studies conducted on NPOs have adopted Stewart and Ruckdeschel's (1998) classification (Martínez-Torres, 2006; Kong, 2010; Mesa, 2010; Adnan et al., 2013; Ramírez and Gordillo, 2014; Ramirez et al., 2016; Hashim et al., 2018; Iqbal et al., 2019). Accordingly, the present study follows the same approach. A definition of each of these elements is provided below. 
$\mathrm{HC}$ contains various elements of human resources such as attitude, tacit knowledge, competencies, innovativeness, skills, experience and talents of individuals (Choo and Bontis, 2002). HC is regarded as a source of organisational innovation and strategic renewal (Bontis et al., 2000; Choo and Bontis, 2002). Therefore, the higher the level of $\mathrm{HC}$, the greater the productivity level, thereby resulting in higher compensation for employees (Wilson and Larson, 2002).

$\mathrm{SC}$ is the capital, which remains at the organisation when employees leave (Ordóñez de Pablos, 2004). It encompasses an organisation's non-human resources such as databases, process manuals, organisational charts, infrastructure, innovation, communication system, strategies and so on (Bontis et al., 2000; Kalkan et al., 2014). SC is regarded as the backbone for $\mathrm{HC}$ and $\mathrm{RC}$, as it involves all forms of non-human knowledge that facilitate and support an organisation's operations, thus contributing to performance and material value (Bontis et al., 2000; Ordóñez de Pablos, 2004).

$\mathrm{RC}$ relates to the flow of knowledge from an organisation to the external environment. This includes the organisation's reputation and influence over the distribution channel, suppliers and clients, as well as governments and industry associations (Grasenick and Low, 2004). RC emerges from the formal and informal relationships that an organisation might possess with external stakeholders and their perceptions of the organisation (Marr and Roos, 2005). In addition, the knowledge exchange between the organisation and its external stakeholders is a major contributing factor to RC (Grasenick and Low, 2004). RC is regarded as important to organisations because of its performed role as a multiplying component that generates and creates values for organisations by linking all IC components with other external stakeholders (Ordóñez de Pablos, 2004).

\section{The importance of intellectual capital in non-profit organisations}

The utilisation of knowledge has long been a topic of interest in strategic management literature, with some scholars suggesting that it is linked with the creation and maintenance of competitive advantage (Nonaka, 1994; Dyer and Nobeoka, 2000). One way in which knowledge can be conceptualised is through the study of IC (Roos and Roos, 1997; Bontis, 1998). IC demonstrates the embedded collective knowledge in the organisation's employees, routines and network relationships (Bontis, 2003). According to Edvinsson and Malone (1997), IC represents "an organisation['s] possession of applied experience, knowledge, professional skills, technology and customer relationships, which result in a market competitive advantage". The IC concept can be applicable to any organisation, irrespective of it being profit-oriented or not (Kong and Thomson, 2006). Therefore, IC is regarded as a fundamental resource, which all NPOs should develop and invest in, for the sake of attaining a sustainable competitive edge in the market.

Since the 1980s, the shifting landscape of the public sector environment has driven NPOs to implement changes in their spheres of endeavor because of the excessive use of competition, commercialisation and contracting in service delivery. Today, NPOs generally operate in a highly complex and competitive environment, characterised by the rising demand for services and facilities from the society, massive competition over contracts between the public sector and profit-oriented sectors, a declining trend in volunteer support and (most importantly) increasingly restricted government funding (Kong, 2010).

Nevertheless, IC has been developed primarily as a framework that is used to investigate the influence of hidden resources (intangible assets) on profit-oriented organisations (Roos et al., 2001). Also, it is substantial for NPOs, as maximizing profits and returns are not regarded as the main target of these organisations. NPOs' revenues are derived from several sources, including government funds, service consumers, fundraising, membership fees, 
rentals from investments, etc (Lyons, 2001). NPOs' ability to accomplish their goals, therefore, relies mostly on the knowledge, skills and experience of their paid employees and volunteers (Hudson, 1999; Laallam et al., 2020). Thus, NPOs tend to invest in and capitalise on people rather than on profits. However, most strategies being adopted by NPOs are considered ineffective, and many of them result in shortfalls in competent management. Ideally, these shortfalls should be rectified and resolved through the lens of IC: this is because the IC approach concentrates on competence development rather than cash flow enhancement (Mouritsen, 1998). It emphasises processes and methods rather than financial results (Edvinsson and Malone, 1997). It focusses on hidden resources rather than tangible ones (Stewart, 1994), and generally fosters inventiveness and creativity among all of an organisation's members so as to reinforce the future of its non-financial forecasts (Mouritsen, 1998). Therefore, a focus on IC is a good fit for NPOs as their main objectives are social in nature rather than economic (Hudson, 1999). In contrast to management methods and techniques in for-profit organisations, NPOs can prevent an identity threat by capitalising on IC as a strategic tool to foster and enhance their efficiency and effectiveness (Alexander, 2000; Sawhill and Williamson, 2001). It can be clearly seen that NPOs nowadays are becoming more obliged to adopt monitoring, control and evaluation processes such as quality management systems, benchmarking and re-engineering of business processes. As a consequence, they are being held liable and accountable for funding and supervisory bodies in the same way as their for-profit counterparts (Courtney, 2002).

\section{Intellectual capital in non-profit organisations}

In the past few decades, commercialisation has become a common feature in many NPOs. This shift has caused the non-profit environment to become highly competitive, which has, in turn, jeopardised the social mission of NPOs. Also, NPOs' concerns have shifted towards performance assessment according to financial measures. Consequently, the concept of IC is considered crucial, as it helps NPO managers to recognise and visualise the importance of knowledge in their organisations. Furthermore, it assists them in balancing the usage of the current and expected intellectual resources within the highly competitive environment in which NPOs currently operate. Moreover, it guides NPO managers to rethink their missions and targets. In other words, it helps in the realignment of objectives towards a social mission, considering learning and knowledge-sharing for the sake of reconciling business and commercial goals for organisational survival and social missions (Mouritsen et al., 2005; Kong and Prior, 2008).

The three IC elements, $\mathrm{HC}, \mathrm{SC}$ and $\mathrm{RC}$ are better regarded to have a synergistic effect. In other words, they must be combined for better results. The interactions between each component represent a series of procedures, which are fundamental to the conduct of NPOs' operations. Knight (1999, p. 24) observed:

As investments are made in human capital, more competent and capable people develop better structural capital for an organisation. Improved human capital and structural capital go on to create more productive external [relational] capital through the delivery of better products and services to high-value customers [...] a virtuous cycle begins its upward spiral into further organisational value and growth.

The IC concept offers another crucial strategic insight regarding value creation, which is assumed to be enhanced and improved when the interrelationships among IC elements are managed efficiently (Cuganesan, 2005). The knowledge transfers created from IC components' interactions are the main generators of IC competitive advantage in NPOs (Figure 1 and Table I). An IC framework highlights knowledge 
Figure 1.

Conceptual framework of IC and competitive advantage in NPOs

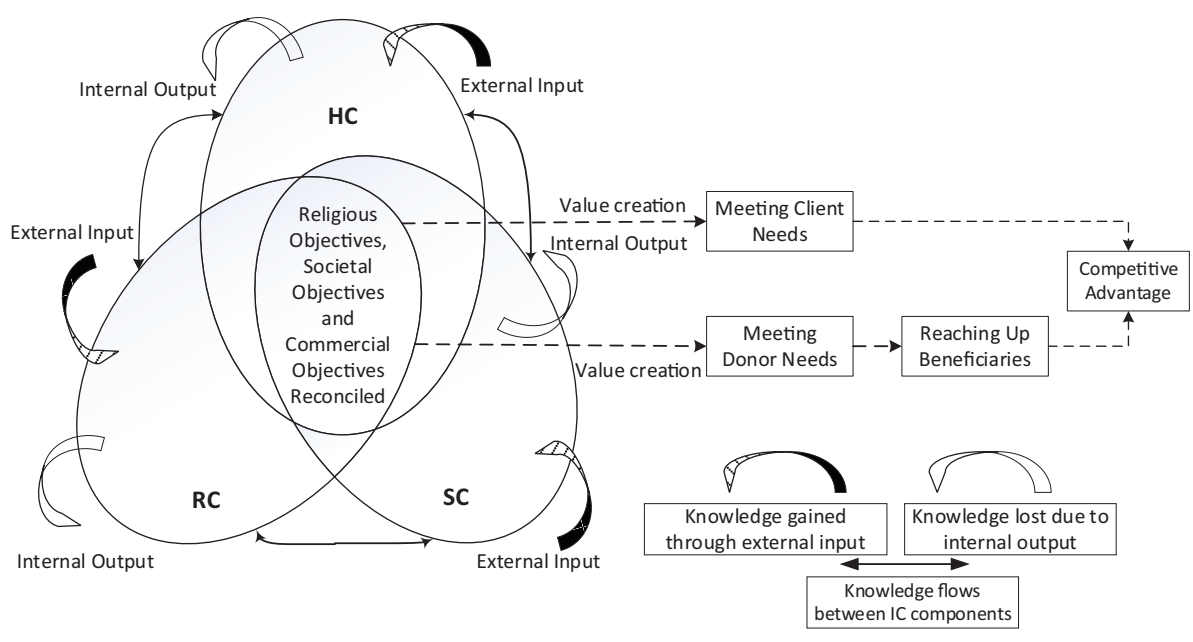

Source: Adapted from Kong and Prior (2008)

The transfer of knowledge from The transfer of knowledge from RC The transfer of knowledge from SC $\mathrm{HC}$ to $\mathrm{RC}$ to $\mathrm{SC}$ to $\mathrm{HC}$

The staff members of NPOs Client, donor and beneficiary present research on behalf of their profiles are input into an organisations at local and international symposiums, seminars, roundtables and conferences

Non-profit staff members build a strong relationship with the external environment such as companies, banks, government bodies and other NPOs

Non-profit staff members are motivated to shift jobs to meet up with clients and donors

Non-profit staff members are highly active and motivated to seek new donors and clients The staff members of NPOs conduct face-to-face surveys of clients, donors and beneficiaries The staff members of NPOs innovate ways to raise transparency 24 h-online enquiry available to the public

\section{organisation's system databases} Clients and donors participate in organisational survey and provide feedback

Information about potential beneficiaries is input into system databases in accordance with donors' wishes

Data input on periodic monitoring of beneficiaries' conditions and development assessment Clients and donors can reach NPOs easily and ask for information NPOs make organisational information available to the public on their websites

Periodically, clients and donors are provided with organisational publications and newsletters
Newly hired staff members of NPOs familiarise themselves with internal organisational manuals and policies The staff members of NPOs analyse clients' profiles to understand their needs

Existing non-profit staff members analyse beneficiary profiles to meet donors' needs

The staff members of NPOs analyse the profiles of clients to come up with new and innovative ideas and methods to better serve their clients Non-profit staff members analyse donors' profiles to invent new ideas and processes to meet donors' needs Senior management formulates and prepares strategic plans of organisations The staff members of NPOs formulate training manuals for newly hired staff and volunteers The staff members of NPOs undergo trainings and workshops on a regular basis

Source: Adapted from Kong and Prior (2008) 
flows within and outside the NPOs' borders and connects them with possible implications for value creation. This enables NPO managers to derive and grasp a clearer image of how IC elements influence their organisations' ability to build and sustain competitive advantage (Kong and Prior, 2008).

\section{Intellectual capital across non-profit sectors}

In the era of k-economies, successful organisations are those that place high importance on IC within their own borders. IC can later be translated into enhancement of an organisation's activities and performance, thereby allowing them to gain competitive advantage within the market they operate in. Nowadays, almost all NPOs across different industries recognise the importance of IC. For instance, in Spain, Ramírez et al. (2007) conducted a case study in the context of the learning environment in an effort to provide new measurements and techniques to help Spanish universities identify, monitor and measure their intangible assets to improve the efficacy and efficiency of their management.

Similarly, Bornemann and Wiedenhofer (2014) applied the concept of IC as a key driver for performance in the Austrian educational stages from pre-school until the tertiary level. The study inquires about the importance of differentiating among IC indicators for each type of organisation to come up with a standardised IC method. The study revealed that monitoring intangible resources in both public and private educational institutions contributes effectively to economic development and the achievement of strategic objectives. In another case conducted in the British context, Bezhani (2010) examined the level of IC reporting at 30 universities. The findings showed that universities in the UK were overregulated and had low awareness of IC.

In the microfinance industry, Kamukama (2013) conducted a study to examine the individual impact of IC components on the competitive advantage of 78 Ugandan microfinance institutions (MFIs), using a survey questionnaire distributed to directors and senior staff of MFIs. The empirical findings of the cross-sectional data showed that all IC elements significantly influenced the competitive advantage of Ugandan MFIs. In other words, it confirmed IC components as strong indicators of competitive advantage. In another study spanning 22 countries, Hashim et al. (2018) examined the effect of IC elements on the performance of MFIs. A survey questionnaire was structured and distributed to around 300 microfinance managers. The empirical results showed a significant relationship between IC elements and the performance of MFIs.

In the art industry, Mesa's (2010) case study explains the way IC is used and applied in two non-profit symphony orchestras in Denver, the USA, from an organisational behaviour standpoint. The author considered only humans and SC in his research as they are more relevant to community orchestras. The author used observations from the field, interviews with the principals, non-principals and board members of orchestras, and literature to identify IC elements. For HC, the emphasis was on identification of scripts, identities of volunteers and their aims; and for SC, attention was given to social structure. The study provided an understanding of how managing IC can direct the resources in NPOs towards enhancing and changing people's lives as employees and volunteers. In short, the study proposed management guidelines for non-profit orchestras to enhance volunteer participation, incentives and personal goal fulfilment.

In Australia, Kong and Thomson (2006) explored the association between IC and strategic human resource management (SHRM). The aim was an enhancement of the services provided by social service NPOs to their stakeholders through improving SHRM and capitalizing on the k-economy. The authors used a series of in-depth semi-structured 
interviews with 35 senior executive managers of the Australian social services NPOs (SSNPOs). The findings indicated that IC should be regarded as a holistic concept, which drives and guides HRM practices in SSNPOs. Furthermore, IC is perceived to assist NPO managers in formulating long-term development strategies. It also provides a better understanding of the utilisation of the current human and non-human resources in their organisations. Most importantly, managers consider the $\mathrm{HC}$ theme - through employing the right people or having them in the right positions - as the determining factor in the success or failure of all participants in the Australian SSNPOs.

In the context of religious organisations, Adnan et al. (2013) conducted a study to investigate the relationship between IC elements and the performance of zakat institutions in Malaysia. A survey questionnaire was distributed to employees of 12 Malaysian zakat institutions. The outputs showed that $\mathrm{HC}$ and $\mathrm{RC}$ had a positive and significant impact on the performance of zakat institutions. However, SC turned out to have no impact. In the context of churches, Freeburg (2016) conducted a study to propose guidelines on how leaders in US churches should approach problems related to IC assets, for the sake of helping church leaders create values that enrich people's lives in the community.

Through the review of previous studies on IC in the context of NPOs across different sectors, it can be clearly observed that most NPOs nowadays consider the importance of realizing IC for achieving objectives and enhancing performance. Therefore, waqf institutions are advised to consider investing in IC for the sake of performance enhancement. It is in the interest of waqf institutions to be discussed within the NPO context, to provide a motive for them to improve, and to consider competition to ensure development on a continuous basis. Moreover, waqf is a unique and flexible activity that can be integrated with almost all other NPO activities such as education, healthcare, social life, religious aspects and so on. Therefore, waqf has to be seen as a holistic system that contributes to the societal and economic development of communities.

\section{Problems of current waqf management and reform trends through intellectual capital}

The level of performance shown by waqf management will be directly reflected in the effectiveness of the waqf institution and its ability to survive and continue to provide benefits and services to the community. There exist several problems and challenges that curb the performance of waqf institutions. These problems include but are not limited to:

- direct intervention of the state in the affairs of waqf;

- weak legal protection;

- low level of awareness about waqf in the community; and

- corruption, etc.

This paper examines some of these issues and proposes solutions to some of them.

\section{Problems related to government administration of awqāf}

Several studies on the development of the waqf institution and its contribution towards developing Muslim societies agree that the direct intervention of the state in the management and direction of waqf can be regarded as one of the main obstacles to the development of the waqf sector in general and the waqf administration in particular. The direct link of $a w q \bar{a} f$ (plural of waqf) to government administration has resulted in many disadvantages and problems, which the awq $\bar{a} f$ sector still suffers from in many Muslim 
countries (Al-Hourani, 2003; Al-Nadjar, 2006; Mohsin, 2010; Mansouri, 2013; Rashid, 2018; WBG, INCEIF and ISRA, 2019). These problems can be summarised as follows.

The lack of a sound legal framework for waqf institutions. The weakness of the waqf legal frameworks in many Muslim countries is a direct factor in limiting waqf performance and its effectiveness in societies. Many awqāf in Muslim countries are difficult to institutionalise as a result of their direct association with state supervision, which makes them an integral part of state administration. Also, most awqāf directly supervised by governments lack standards of governance, transparency and professional management (Mohamad and Ariff, 2016; Binghaia and Kassim, 2017; Latif et al., 2018; WBG, INCEIF and ISRA, 2019). For instance, in Algeria awq $\bar{a} f$ are directly governed and controlled by the state under the Ministry of Religious Affairs and Awqaf. In addition, the laws governing awqa $f$ in Algeria are outdated and strictly limit their performance (Hadadou and Al-Nahwi, 2019). In Malaysia, Latif et al. (2018) conducted a study for the sake of understanding the problems related to waqf governance in Kelantan. The findings indicated that legislation and insufficient management are among the factors impeding good implementation of governance in waqf.

Although many Muslim countries, such as Egypt, Sudan and Jordan, have taken consideration of this issue and granted partial independence of awqa $f$ to sub-administrators, the problem of centralisation nevertheless persists (Bakar et al., 2017; Rashid, 2018; A1Snousi, 2019). For example, in his book on awqāf, society and politics in Egypt, Ghanem (2015) pointed out that government policies towards the awqāf system in Egypt have gradually subjected the waqf sector to the centralisation and authority of the state, starting from administrative aspects and moving on to restricting it in legislative aspects as well. This has moved the waqf system away from decentralisation (as an independent entity) and community participation to the central tendency of the state serving specific public policies (Ghanem, 2015). Similarly, Mohsin (2010) and Rashid (2012) pointed to restrictions in waqf laws with regard to family waqf in most Muslim countries, and called for revisiting their current status.

Therefore, experts and researchers emphasise the need to grant awqāf institutional independence for the sake of performance enhancements and the need to enact laws that allow the establishment, development, investment and management of awqāf to better serve the will of the wäqif (endower) and the interest of the waqf and society (Mohsin, 2010; Mansouri, 2013; Iman and Mohamad, 2014; Rashid, 2018; Hadadou and Al-Nahwi, 2019; WBG, INCEIF and ISRA, 2019). It is worth noting that the role of the state in nurturing waqf institutions in terms of indirect supervision and enactment of laws can never be overemphasised (Rashid, 2018); however, semi-independence is very important. Good examples of independent entities involved in the management of awq $\bar{a} f$ are the General Secretariat of Awqāe in Kuwait and Warees[2] in Singapore.

Poor performance efficiency. The weakness of performance in the management of awqāf is one of the results of governmental intervention in the affairs of waqf administration, which impedes its performance enhancements. This is a chronic problem inherited from the traditional system in the management of $a w q \bar{a} f$, which resulted in low rates of return on $a w q \bar{a} f$ asset investment, leading to a decline of waqf activities in the society. Poor performance in waqf management and administration can be attributed to several factors, the most important of which are:

- Lack of quality standards for recruitment, training and staff development programmes in the awq $\bar{a} f$ sector. Also, most employees of the waqf sector are not linked to the waqf except through government jobs (Mansouri, 2013; Abas and Raji, 2018; Latif et al., 2018; WBG, INCEIF and ISRA, 2019); 
IJIF

12,1

- Lack of qualified and trained labour for the management of awqāf results in low productivity of the awq $\bar{a} f$, which affects the continuity and sustainability of the investments in the sector. It was also discovered that the lack of skills and required competence in waqf employees is a direct result of poor academic or functional specialties for the positions required, as well as weak training programmes provided to waqf staff (Al-Salahat, 2003; Binghaia and Kassim, 2017; Rusydiana and Devi, 2018);

- Although waqf administration staff are enriched with long administrative experience, this does not serve the interest of the waqf. This is because, the administrative positions are not linked to incentives for achievements, which undermines the higher interests of the waqf;

- Waqf administration suffers from malfunction in the workflow system and incompetent workforce; the waqf activities require many professional experts such as engineers, contractors, media professionals and investment management specialists. This explains the gap between the waqf management requirements and the actual organisation of the workers' system; and

- Little reform efforts are directed towards waqf institutions; they have been left to neglect and idleness. Meanwhile, new charitable and voluntary institutions are being established to fill the social vacuum resulting from government mismanagement of awqāf (Mansouri, 2013).

Institutional corruption in government awqāf management. Corruption in the traditional waqf administration has turned into institutional corruption within the governmental waqf administration. It has become wider and more damaging. Modern technologies and administrative regulations enacted by successive waqf laws have not succeeded in closing the administrative corruption gap in waqf administration (Ghanem, 2015; Osbehi, 2015; Rusydiana and Devi, 2018). According to Mansouri (2013), "legal" gaps have made it difficult to deal with administrative corruption.

Weak legal protection for public waqf. In some countries of the Muslim world, public $a w q \bar{a} f$ are treated with carelessness, and the privileges granted to them are very few, although they are closely related to public interest. For instance, in Algeria, Egypt and Morocco, there are no effective tools to protect the public waqf from encroachments by individuals and the state itself because of the weakness of waqf legal frameworks (A1Nadjar, 2006; Ghanem, 2015; Osbehi, 2015; Hadadou and Al-Nahwi, 2019). The absence of such tools enables individuals to encroach upon the property of waqf and claim ownership. It also facilitates the administrators exceeding the limits laid down by the law to exercise the power of expropriation for the public benefit, which was exercised on waqf properties without limits or controls (Al-Nadjar, 2006; Ghanem, 2015). The infringement on the properties of the public waqf has been legitimised by forcing the Ministry of Awqaf and Islamic Affairs as a government sector to exclude seeking judicial remedies and accept instead consensual settlements that violate the rights of public awqa $\bar{f}$ under the pretext of the duty of government solidarity (Osbehi, 2015).

Lack of information, communication and documentation systems. Information, communication and documentation systems in government awqa $f$ departments have long been rudimentary in many Muslim countries (Rashid, 2012; Daud, 2018; Khamis and Salleh, 2018; Rusydiana and Devi, 2018; WBG, INCEIF and ISRA, 2019). They are governed by old laws and regulations that no longer fit the circumstances of the time and the living reality (Hadadou and Al-Nahwi, 2019). They are far from benefiting from the information and 
communication technology products of modern management and financial technologies (fintech) (Ghanem, 2009, 2015; Rashid, 2018). In addition, there are issues of bureaucracy, conflicts of interest and lengthy documentation processes (Daud, 2018). Most awq $\bar{a} f$ departments are still using manual methods in most of their programmes, which deal with a large number of documents relating to waqf deeds, assets and donors (Al-Humaidan, 2006; Rusydiana and Devi, 2018).

Low social and economic benefits of waqf. The waqf administration under direct government supervision has contributed in one way or another to limiting the concept of waqf to a narrow area, namely, the religious sphere (Al-Nadjar, 2006; Mohamad and Ariff, 2016). In some Muslim countries such as Algeria, waqf services are no longer known to the public, except the work relating to the construction and maintenance of mosques and the ongoing charity of mosques. Thus, the scope of waqf has ceased to be comprehensive and its social repercussions have been reduced. Waqf grants have been limited to traditional and stereotyped areas of assistance and charitable activities. These activities have not changed according to the needs and development of the society (Mansouri, 2013; Hadadou and Al-Nahwi, 2019). Furthermore, traditional methods of investment, distribution and the length of governmental procedures, from the period of maturity to distribution, have reduced the social benefits of the waqf (Rashid, 2012; AlOmar, 2013; Mohamad and Ariff, 2016). The weakness of the economic productivity of $a w q \bar{a} f$ is because of the weakness of the governmental awqa $\mathrm{a}$ administration in the field of waqf fund investment (Ahmad and Karim, 2019).

High cost of waqf management and the diminishing developmental impact of waqf. Government control over waqf management has led to the diminution of the awqāf's developmental effect, which has reduced the revenues paid to beneficiaries. Moreover, in some instances productive waqf assets are left idle because of insufficient revenues to sustain operational costs (Chowdhury et al., 2011; WBG, INCEIF and ISRA, 2019). This highlights the need to assign independent and professional bodies or institutions to manage awq $\bar{a} f$ in Muslim countries (Rashid, 2018; WBG, INCEIF and ISRA, 2019).

Decline of waqf activities in the community. The status of waqf under the tutelage of governments in many Muslim countries has led people to refrain from waqf because they believe that the state provides social services. The weak contribution of waqf in social or developmental activities has reduced the community orientation towards waqf (Abū Zahrah, 1971; Rashid, 2012; Mansouri, 2013). Governmental supervision of waqf linked many of the waqf's tendencies and distribution of revenues to government policy, which led to the performance of waqf being linked to the efficiency of the government apparatus (A1Nadjar, 2006; Ghanem, 2015; Obaidullah and Shirazi, 2017).

The state's behaviour towards waqf funds led to the decline of waqf and the undermining of the trust of the public in waqf administration (Qabbani, 2003; Obaidullah and Shirazi, 2017; Rusydiana and Devi, 2018; WBG, INCEIF and ISRA, 2019). For instance, in research conducted to identify the most problematic issues confronting the performance of awqāf globally, Rashid (2012) called for the democratisation of waqf administration to give room to Muslim public participation for the sake of diluting the present state control over awq $\bar{a} f$. The rate of establishment of new awq $\bar{a} f$ was observed to be on the decline when the Ministry of Awqaf control over waqf revenues and distribution. This may not be disconnected with the undue powers and influence of government officials, as seen in Egypt's legislation whereby the minister is given the right to dispose of awqā $f$ revenues at his volition (Al-Nadjar, 2006; Ghanem, 2015). Public opinion has, therefore, developed a perception of waqf's ineffective performance, which has led to doubts about the credibility of the government administration in the management of awqā f(Al-Omar, 2013). 
Weakness of waqf's connection with civil society institutions. The governmental organisation for $a w q \bar{a} f$ management has weakened the link between $a w q \bar{a} f$ and civil society institutions. The Ministry of Awqaf has transferred the waqf distributions and revenues, which had originally been allocated to support national charities such as hospitals, schools and other private institutions, to the current expenditure of the Ministry of Awqaf. The revenues have also been used for other distributions, which do not represent the needs of the community as expressed by civil organisations. In addition, most modern laws of the awqāf seek to restrict the family waqf, which has been a lifeline to charitable waqf, and then decrease the number of family awq $\bar{a} f$, which were often administered by institutions of civil society. Thus, these limitations have weakened the role of the waqf and reduced its spending on public services, including civil society organisations (Mohsin, 2010; Rashid, 2012; AlOmar, 2013; Ghanem, 2015).

\section{Reform trends in government waqf administration}

The contemporary reality of waqf administration has revealed the lack of administrative performance in general and the weakness of government administration over awq $\bar{a} f$ in particular (Rashid, 2012; Ahmad and Karim, 2019; Saiti et al., 2019). This includes all organisational aspects of the institutional structure, which has led many Muslim countries to adopt reform projects and programmes aimed at the protection, modernisation and development of awqā $f$. These reforms are centred on three main axes, all of which can be enhanced effectively by varying degrees through the consideration of IC.

Administrative reform. The first step in the overall reform process in many Muslim countries is through the supervisory and administrative apparatus of the awqāf, as well as its administrative development. Legal reform, although still suffering from many shortcomings, has paved the way for the development of supervisory and administrative bodies. It has also enhanced the ability of waqf institutions to serve their objectives. It is imperative to overcome the challenges curbing the efficiency and effectiveness of the current awq $\bar{a} f$ mentioned above. This can pave the way to restoring the role of the waqf institution in leading the social and economic development of countries (Rashid, 2018).

IC elements play the most important reform role within the administrative aspects and act as a backbone for other reforms. This is because IC starts with the recognition of an organisation's resources within its borders, building upon the three main strength elements, namely, $\mathrm{HC}, \mathrm{RC}$ and $\mathrm{SC}$ - thereby affecting organisational performance.

Legal reform. Many Muslim countries have made varying efforts to codify and legislate all matters related to waqf in accordance with the provisions of the Shari' ah (Islamic law). They have sought to regulate waqf affairs by enacting laws and regulations to achieve full compliance with the principles of legality, as well as criminalizing violations of those principles (Jibril, 2003). The process of codifying waqf provisions in Muslim countries over the course of a century constituted the fundamental turning point in the legal framework of waqf (Ghanem, 2009). Egypt started the first legalisation of waqf in the Arab world in 1946, followed by Jordan, Lebanon, Syria and Kuwait. This process led to the integration of awqāf into the bureaucratic apparatus of the government and the extension of the state's control over the waqf sector. Later on, Algeria issued its Waqf Law in 1991, followed by Yemen, Qatar, Mauritania and the UAE (Ghanem, 2009).

These laws came in response to the urgent need to review waqf techniques, to purify them of contradictions and texts that impeded the freedom of waqf and to achieve a greater degree of administrative independence and legal protection of waqf funds. They further helped to restore and activate the role of waqf institutions in serving the society. Some Muslim countries have responded to scholars and experts' views with regard to the need to 
grant legal and institutional personality to waqf. Thus, Egypt in 1971 established the Egyptian Awqāf Authority to handle all awqāf matters in the Ministry of Awqaf. Sudan took the same approach and established the Federal Corporation of Awqāf in 1987, followed by Kuwait, Jordan, Qatar and Indonesia (Rashid, 2018; Ayuniyyah et al., 2019).

Despite the continuous and tremendous efforts that have been made by many governments over the Muslim world aiming at the development of the waqf sector, many experts and researchers stress the need for the independence of awq $\bar{a} f$ from other state agencies such as the Ministry of Religious Affairs. They stress the need to apply a capital governance system and establish an independent supervisory, administrative and financial system to run the waqf sector to achieve efficiency and effectiveness and to restore the trust and reputation of the waqf system in societies (Mesdour, 2008; Ghanem, 2009; Mansouri, 2013; Osbehi, 2015; Rashid, 2018).

On the other hand, many previous studies have proven that one of the main reasons behind the backwardness of the waqf sector in many Muslim countries is the narrow, regressive and inflexible nature of waqf laws (Rashid, 2018; Hadadou and Al-Nahwi, 2019). The effect of IC components in this reform is, therefore, a secondary or later effect. Waqf institutions can also benefit from IC in terms of investment in building networking and increasing awareness, which can speed up the pace of legal reform.

Financial reform. The financial aspect is one of the axes of the reform that has taken place within the waqf sector. The need for funding, management and investment of waqf funds constituted one of the major problems that hindered the development of the waqf sector. The liquidity shortage suffered by waqf institutions is mainly because of the nature of waqf funds themselves, which are mostly property and agricultural land. Waqf management has been renting these properties and lands for small amounts and for long periods of time (Mansouri, 2013).

To solve the problem of funding and the provision of waqf investment, Muslim countries have resorted to several legislative solutions to allow financing through the use of contemporary Islamic financial instruments. In addition, they introduced the concept of market rental rate (ujrah al-mithl) when renting waqf properties to individuals (Mansouri, 2013).

In view of the limited nature of these solutions, some Muslim countries such as Kuwait, Malaysia, Indonesia and Singapore have taken a different approach to financial reforms in the waqf sector. To address the problem of waqf financing, as well as other problems, they capitalised on more expansive jurisprudential opinions on matters related to the nature of waqf assets and the regulation of their development. These include issues related to cash waqf, replacing waqf assets (istibda $)$ ), and attracting new and highly liquid awqāf (Asmy, 2015; Haji-Mohiddin and Mas, 2015; Rashid, 2018; Thaker et al., 2018; Ayuniyyah et al., 2019).

The direct intervention of governments in many Muslim countries in the management of $a w q \bar{a} f$ has had a negative effect on the awqāf sector. Awqāf have been affected by stagnation, marginalisation and exclusion from the field of social work (Laallam et al., 2020). However, many local and international conditions and developments are pushing those interested in waqf to review and evaluate the experience of the government administration of the waqf sector. This is to provide other effective alternative ways of enhancing the role of waqf in the service of social and developmental projects (Mahdi, 2003). This requires reform in the institutional framework and administrative systems that control the waqf sector through the consideration of IC and knowledge (Laallam et al., 2020).

In many Muslim countries, waqf investment was not based on sound scientific and objective foundations. It was also limited to the self-financing of the waqf institution and was not open to external funding through participation. Hence, the urgent need to adopt and invest in the components of IC, especially RC. On the other hand, development in the 
economic aspects showed the need for joint waqf, waqf $s u k \bar{u} k$, and the inclusion of financial technologies such as blockchain and crowdfunding (Suhaili and Palil, 2016; Rashid, 2018; Thaker et al., 2018; Mohsin and Muneeza, 2019). The current time is considered a time of economic blocs, and trade has become based on joint-stock companies, joint financing, contributions, etc. Therefore, great waqf projects that benefit people cannot depend on only one person (Al-Qurradāghī, 2019). Waqf institutions also need large amounts that must be collected from many people, resulting in the tendency to replace the independent waqf with more economically feasible projects.

It should be noted that crowdfunding, for instance, acts as a new tool of funding waqf projects by raising small amounts of money from a large number of people (Suhaili and Palil, 2016; Rashid, 2018). It represents an updated picture of financing waqf projects jointly. This method follows a sound economic principle, the so-called optimal size of the project; cost is reduced and revenue increases, which means good management of community resources; thus maximizing public benefit (Al-Luwaikh, 2015).

In addition, establishing an international waqf mechanism could contribute to solving the financial problems of waqf. One good example of this is the establishment of the World Waqf Foundation (WWF) as an international entity working under the umbrella of the Islamic Development Bank (IDB) to establish institutions and projects. The objectives of the WWF under the IDB are also to develop, fund and promote programmes, effectively manage $a w q \bar{a} f$ resources and sustain them to contribute to economic and societal development efforts while at the same time adhering to the conditions of donors (Mansouri, 2013; Mimouni and Aouisi, 2018). It is imperative for waqf institutions to invest in IC and to become knowledge organisations, which innovate, plan and invest accordingly, thereby sustaining and developing waqf assets. This necessity becomes even more important when waqf institutions must work under a common or an international entity.

\section{Discussion}

Realizing the importance of having highly qualified and competent employees with diverse specialties and skills would be the cornerstone for the advancement of waqf institutions. $\mathrm{HC}$ is regarded as the focal point of success of any organisation. First and foremost, waqf institutions are required to build and establish an environment that attracts and retains talent by having a strategy of high-quality performance. There is also the need to provide a supportive culture of innovation, openness, continuous learning and development that will then result in efficiency in all organisational aspects. This is unlike the case of most waqf institutions today, particularly those suffering from direct intervention of the state. Therefore, having active and talented workers would energise all organisational aspects, starting with formulating strategic plans to enhance the performance of waqf institutions. This can facilitate sound decisions that would serve the interest of the institutions and the community. This would have a direct effect on the development of the organisational system (SC).

Realizing the importance of SC would spur waqf institutions to consider investing in technology, infrastructure, databases, manuals, etc. Having a strong technology-based system within a waqf institution would facilitate the work of the staff, enhance communication skills and networking and learning, thereby enabling best practices of the sector in a short time and at a minimal cost (time and cost effectiveness). In addition, having a solid infrastructure would improve the working environment and the surroundings of waqf institutions. It can equally introduce a supportive organisational culture, which, in turn, would impact positively on organisational performance. Also, it may improve the living conditions of waqf employees. Moreover, having a strong database and manuals at 
the workplace would help with the codification of knowledge and of the experiences and best practices of the waqf sector.

This would assist in bridging the gap and bringing waqf institutions together across borders, to share their practices and challenges and provide solutions. Correspondingly, it would play a significant role in lessening the loss of knowledge resulting from employee turnover and other human resource issues (Liebowitz, 2006, 2016). Likewise, it would help in speeding up the process of adaptation of new workers and would expose them to the particularities of the waqf sector. Most importantly, it would play a crucial role in capital developing and improving the process of documentation within waqf institutions and minimizing the paperwork that characterises most of them. Additionally, it would help in periodical publications and raising awareness about waqf in the community.

In the context of the world becoming one city as a result of globalisation, waqf institutions have yet to benefit from networking and the building of external relationships with other industries and entities operating in the same environment. These entities include banks, other organisations and waqf institutions operating in other countries. Realizing the importance of RC (external capital) may help waqf institutions in building and establishing networks and new associations that may result in performance enhancement. This may be through joint investments and projects and also through raising awareness of waqf by restoring its vital role in serving the community.

Waqf institutions involved in joint investments and projects may benefit from legal facilities, as most waqf sectors across the world suffer from weak legal systems that have kept waqf chained for decades. Therefore, the presence of waqf institutions across jurisdictions through the implementation of joint waqf projects and investments may speed up the process of reviewing the legal system of waqf institutions in different countries. In addition, these networks and associations would lead waqf institutions to adopt some of the behavioural patterns of profit-making organisations. At the same time, they can help to keep waqf institutions updated with environmental changes taking place in today's world. Above all, realizing the importance of IC would benefit waqf institutions in retrieving "the spirit of organization", as most awqāf in the Muslim countries are still under the mercy and direct control of the state, which restricts their performance and productivity and silences their name and role in the Muslim community.

\section{Conclusion}

So far, this study highlights the importance of realizing and investing in IC as a solution for all NPOs in general and waqf organisations in particular. In view of the importance of IC in assisting NPOs to achieve a competitive edge in the current complex environment, Muslim countries may benefit from the experience of other NPOs in the development of the waqf sector. This may contribute to retrieving the legal and institutional personality of $a w q \bar{a} f$ in many Muslim countries. Observers of the living reality of awq $\bar{a} f$ around the Muslim world today note many challenges and constraints that prevent the fulfillment of the waqf's role in serving and developing societies. Most of these problems are common in nature and can be linked in one way or another to the state's direct control and management over the waqf sector. With the increasing responsibilities of states, retrieving the role of the waqf institution in societies has emerged as a necessity. The waqf institution has to be restored to its key position - that of the head of the third sector - for the sake of bridging the social and economic gaps in Muslim societies.

This study contributes to the literature in relation to waqf management through various ways. First, it highlights the importance of IC through reviewing a significant body of research in the context of NPOs. Second, it identifies challenges of current waqf 
management that constrain the performance of waqf institutions, which include direct intervention of the state in the affairs of waqf, weak legal protection, low level of awareness about waqf in the community and corruption. The study critically provides insights into the reform trends, which include administrative, legal and financial reforms. The study proposes some solutions to the challenges faced by waqf institutions, notably: building and establishing an environment that attracts and retains talent; investing in technology, infrastructure, databases and manuals; and establishing networks and new associations through the implementation of joint investments and projects that may result in overall waqf performance enhancement. The study puts forward some policy suggestions, which in the long run can enable waqf institutions to survive and continue to provide benefits and services to the community. To our knowledge, this is a pioneer study, which examines the problems of current waqf management and reform trends through IC.

Although this study proposes solutions to some challenges confronting waqf performance by focussing on the elements of IC, these solutions remain limited because of the necessity of granting awq $\bar{a} f$ the independence in authority and decision. In addition, there is a need for the state to provide waqf institutions with indirect supervision and enact necessary laws that contribute towards the development of awqāf that would serve Muslim societies.

\section{Note}

1. Knowledge flow is the passing of knowledge between nodes according to certain rules and principles. It helps making knowledge available and accessible by staff using easy-to-read templates and smart learning on a continuous basis, which results in performance enhancements at the end (see: www.igi-global.com/dictionary/knowledge-flow-identification/16342).

2. Warees acts as the waqf agent of Majlis Ugama Islam Singapura.

\section{References}

Abas, F.N. and Raji, F. (2018), "Factors contributing to inefficient management and maintenance of waqf properties: a literature review", Umran - International Journal of Islamic and Civilizational Studies, Vol. 5 No. 3, pp. 53-67.

Zahrah, A. (1971), Muhā darāt fì al-Waqf, Dār al-Fikr al- 'Arabī, Cairo.

Adnan, N.S., Kamaluddin, A. and Kasim, N. (2013), "Intellectual capital in religious organisations: Malaysian zakat institutions perspective", Middle East Journal of Scientific Research, Vol. 16 No. 3, pp. 368-377.

Ahmad, A.U.F. and Karim, M.F. (2019), "Opportunities and challenges of waqf in Bangladesh: the way forward for socio-economic development”, in Ali, K.M, Hassan, M.K. and Saaid Ali, A.E.E. (Eds), Revitalization of Waqf for Socio-Economic Development, Vol. 1, Palgrave Macmillan, Cham, pp. 193-212.

Alexander, J. (2000), "Adaptive strategies of nonprofit human service organizations in an era of devolution and new public management", Nonprofit Management and Leadership, Vol. 10 No. 3, pp. 287-303.

Al-Hourani, Y. (2003), "Al-Binā' al-Mu'assasī li al-Waqf fī buldān al-Hilāl al-Khașīb”, in Al-Bayoumi Ghanim, I. (Ed.), Nižām al-Waqf wa al-Mujtam al-Madanī fì al-Wațan al-'Arabì, Markaz Dirāsāt al-Wịhdah al-'Arabiyyah, Beirut, Lebanon, pp. 557-581.

Al-Humaidan, I. (2006), "Dawr al-Nuzum al-Ma 'umātiyyah fī da 'm kafā’ at al-Qitā̄' al-Waqfī”, Majalat Awqāf, Vol. 14 No. 10, pp. 123-136. 
Al-Luwaikh, A. (2015), "Waqf mushtarak, mu'ayyan, mushā', paper presented at Nadwat al-Awqāf wa al-Qadā', 20-22 March, Saudi Arabia, available at: www.alukah.net/library/0/92206/ (accessed 2 December 2018).

Al-Nadjar, A. (2006), Wilāyat al-Dawlah 'atā al-Waqf: Al-Mushkilah wa al-Hulūl, Jāmi 'at Umm AlQurā', Makkah.

Al-Omar, F.A. (2013), The Contribution of Waqf to Non-Governmental Work and Social Development, Kuwait Awqâf Public Foundation, Kuwait.

Al-Qurradāghī, A. (2019), "Al-Awqāf al-Mushtarakah bayn al-Muslimīn wa ghayrihim", Muntad̄̄ Qad̄àya al-Waqf al-Tāsi, Jordan, pp. 1-31.

Al-Salahat, S. (2003), "Al-Tajrubah al-Waqfiyyah li-Dawlat al-Imārāt al-'Arabiyyah alMuttahidah, imārat al-Shāriqah namūdhaja, 1996-2002”, Majallat Awqāf, Vol. 17 No. 5, pp. 41-89.

Al-Snousi, A. (2019), "Raqābat al-Dawlah 'alā al-Waqf: Mādịhā, wa hādiruhā, wa āfāquhā", Hawliyat Jami at al-Jaz'ir 1, Vol. 33 No. 2, pp. 446-476.

Asmy, M. (2015), "A proposed integrated cash waqf micro enterprise investment (CVVME-1) model for mitigating the financial and human capital development challenges of micro enterprises in Malaysia", $\mathrm{PhD}$ thesis, International Islamic University Malaysia.

Ayuniyyah, Q., Devi, A. and Kartika, T. (2019), "The Indonesia waqf board (BWI): an analytical network process analysis", in Ali, K.M, Hassan, M.K. and Saaid, A.E.A. (Eds), Revitalization of Waqf for Socio-Economic Development, Palgrave Macmillan, Cham, pp. 207-228.

Bakar, N.A.A., Hussain, M.N.M. and Hamed, A.B. (2017), "Exploring the factors of organization structure to improve waqf management in Malaysia", International Journal of Business, Vol. 2 No. 2, pp. 79-88.

Bezhani, I. (2010), "Intellectual capital reporting at UK universities", Journal of Intellectual Capital, Vol. 11 No. 2, pp. 179-207.

Binghaia, M. and Kassim, S. (2017), "Issues and challenges in management of waqf in Ningxia province of China", Journal of Islamic Finance, Vol. 176 No. 6298, pp. 1-14.

Bontis, N. (1998), "Intellectual capital: an exploratory study that develops measures and models", Management Decision, Vol. 36 No. 2, pp. 63-76.

Bontis, N. (2003), "Intellectual capital disclosure in Canadian corporations", Journal of Human Resource Costing and Accounting, Vol. 7 No. 1, pp. 9-20.

Bontis, N., Keow, W.C.C. and Richardson, S. (2000), "Intellectual capital and business performance in Malaysian industries", Journal of Intellectual Capital, Vol. 1 No. 1, pp. 85-100.

Bornemann, M. and Wiedenhofer, R. (2014), "Intellectual capital in education: a value chain perspective", Journal of Intellectual Capital, Vol. 15 No. 3, pp. 451-470.

Bronzetti, G., Mazzotta, R., Puntillo, P., Silvestri, A. and Veltri, S. (2011), Intellectual Capital Reporting Practices in the Non-Profit Sector, Virtus Interpress, Sumy, Ukraine.

Choo, C.W. and Bontis, N. (2002), The Strategic Management of Intellectual Capital and Organizational Knowledge, Oxford University Press, New York, NY.

Chowdhury, M.S.R., Ghazali, M.F. and Ibrahim, M.F. (2011), "Economics of cash waqf management in Malaysia: a proposed cash waqf model for practitioners and future researchers", A frican Journal of Business Management, Vol. 5 No. 30, pp. 12155-12163.

Cohen, S. and Vlismas, O. (2013), "Analyzing the relationship between intellectual capital and performance in local governments", Global Business and Economic Review, Vol. 15 Nos 2/3, pp. 1-17.

Considine, M. (2003), "Governance and competition: the role of non-profit organisations in the delivery of public services”, Australian Journal of Political Science, Vol. 38 No. 1, pp. 63-77. 
Courtney, R. (2002), Strategic Management for Nonprofit Organizations, Routledge, London.

Cuganesan, S. (2005), "Intellectual capital-in-action and value creation: a case study of knowledge transformations in an innovation project", Journal of Intellectual Capital, Vol. 6 No. 3, pp. 357-373.

Daud, D. (2018), "Insight into the reasons for the lack of waqf reporting", Journal of Emerging Economies and Islamic Research, Vol. 6 No. 3, pp. 48-58.

Dyer, J.H. and Nobeoka, K. (2000), "Creating and managing a high-performance knowledge-sharing network: the Toyota case", Strategic Management Journal, Vol. 21 No. 3, pp. 345-367.

Edvinsson, L. and Malone, M.S. (1997), Intellectual Capital: Realizing Your Company's True Value by Finding Its Hidden Brainpower, HarperCollins, New York, NY.

Freeburg, D. (2016), "Intellectual capital in churches: matching solution complexity with problem complexity", Proceedings of the Association for Information Science and Technology, pp. 1-11.

Ghanem, I. (2009), “The historical formation of the waqf function in the Arab societies”, Nizām al-Waqf Wa al-Mujtama' al-Madañ̄ fì al-Wațan al-'Arabī, pp. 75-109.

Ghanem, I. (2015), Al-Awqāf wa al-Mujtama' wa al-Siyāsah fī Miṣr, Madārāt for Research and Publishing, Cairo.

Grasenick, K. and Low, J. (2004), "Shaken, not stirred: defining and connecting indicators for the measurement and valuation of intangibles", Journal of Intellectual Capital, Vol. 5 No. 2, pp. 268-281.

Hadadou, S. and Al-Nahwi, S. (2019), "Tatawwur al-Sulūk al-Waqfī fī al-Jazā'ir”, Majallat al-Fìkr alQūnūnī wa al-Siyāsì, Vol. 5 No. 1, pp. 1-12.

Haji-Mohiddin, H. and Mas, N. (2015), "Waqf development in Malaysia and Singapore: a comparative study", $\mathrm{PhD}$ thesis, Durham University.

Hansmann, H.B. (1979), "The role of nonprofit enterprise”, The Yale Law Journal, Vol. 89 No. 5, pp. 835.

Hashim, M.J., Adeyemi, A.A. and Alhabshi, S.M. (2018), "Effects of intellectual capital on microfinance institutions' performance", in Noordin, F., Othman, A.K. and Kassim, E.S. (Eds), Proceedings of the 2nd Advances in Business Research International Conference, Springer, Singapore, pp. 187-196.

Hudson, M. (1999), Managing without Profit: The Art of Managing Third-Sector Organizations, Penguin, London.

Iman, A.H.M. and Mohamad, M.T.S. (2014), Waqf Property: Concept, Management, Development, and Financing, Penerbit UTM Press, Skudai, Johor.

Iqbal, A., Latif, F., Marimon, F., Sahibzada, U.F. and Hussain, S. (2019), "From knowledge management to organizational performance: modelling the mediating role of innovation and intellectual capital in higher education", Journal of Enterprise Information Management, Vol. 32 No. 1, pp. 36-59.

Jibril, A.F. (2003), Harakat Taqnīn Ahkām al-Waqf fī Tarīkh Miṣr al-Mu'ạṣir, Kuwait Awqaf Public Foundation, Kuwait.

Kalkan, A., Bozkurt, Ö.Ç. and Arman, M. (2014), "The impacts of intellectual capital, innovation and organizational strategy on firm performance", Procedia - Social and Behavioral Sciences, Vol. 150, pp. 700-707.

Kamukama, N. (2013), "Intellectual capital: company's invisible source of competitive advantage", Competitiveness Review, Vol. 23 No. 3, pp. 260-283.

Khalique, M., Bontis, N., Abdul Nassir bin Shaari, J. and Hassan Md. Isa, A. (2015), "Intellectual capital in small and medium enterprises in Pakistan", Journal of Intellectual Capital, Vol. 16 No. 1, pp. 224-238.

Khalique, M., Shaari, J.A.N. and Md. Isa, A.H. (2013), "The road to the development of intellectual capital theory", International Journal of Learning and Intellectual Capital, Vol. 10 No. 2, pp. 122-136. 
Khamis, S.R. and Salleh, M.C.M. (2018), "Study on the efficiency of cash waqf management in Malaysia”, Journal of Islamic Monetary Economics and Finance, Vol. 4 No. 1, pp. 61-84.

Khosla, R., Chu, M.-T., Doi, S., Yamada, K. and Nishida, T. (2010), "Knowledge flow networks and communities of practice in business process management", in Wang, M. and Sun, Z., (Eds), Handbook of Research on Complex Dynamic Process Management: Techniques for Adaptability in Turbulent Environments, IGI Global, Hershey, PA, pp. 551-572.

Kianto, A., Ritala, P., Spender, J.-C. and Vanhala, M. (2014), "The interaction of intellectual capital assets and knowledge management practices in organizational value creation", Journal of Intellectual Capital, Vol. 15 No. 3, pp. 362-375.

Knight, D.J. (1999), "Performance measures for increasing intellectual capital", Strategy and Leadership, Vol. 27 No. 2, pp. $22-27$.

Kong, E. (2007), "The strategic importance of intellectual capital in the non-profit sector", Journal of Intellectual Capital, Vol. 8 No. 4, pp. 721-731.

Kong, E. (2010), "Intellectual capital and non-profit organizations in the knowledge economy", Journal of Intellectual Capital, Vol. 11 No. 2, pp. 97-106.

Kong, E. and Prior, D. (2008), "An intellectual capital perspective of competitive advantage in nonprofit organisations", International Journal of Nonprofit and Voluntary Sector Marketing, Vol. 13 No. 2, pp. 119-128.

Kong, E. and Thomson, B. (2006), "Intellectual capital and strategic human resource management in social service non-profit organisations in Australia", International Journal of Human Resources Development and Management, Vol. 6 Nos 2/3/4, pp. 213-231.

Laallam, A., Kassim, S., Adawiah, E.R. and Saiti, B. (2020), "Towards knowledge-based waqf organizations", in Saiti, B. and Sarea, A. (Eds), Challenges and Impacts of Religious Endowments on Global Economics and Finance, IGI Global, Hershey, PA, pp. 100-120.

Latif, S.A., Din, N.M.N. and Mustapha, Z. (2018), "The role of good waqf governance in achieving sustainable development", Environment-Behaviour Proceedings Journal, Vol. 3 No. 7, pp. 113-118.

Liebowitz, J. (2006), "Conceptualizing and implementing knowledge management", in Love, P., Fong, P.S.W. and Irani, Z. (Eds) Management of Knowledge in Project Environments, Routledge, pp. 17-34.

Liebowitz, J. (2016), Beyond Knowledge Management: What Every Leader Should Know, CRC Press, Boca Raton, FL.

Lyons, M. (2001), Third Sector: The Contribution of Non-Profit and Cooperative Enterprises in Australia, Allen and Unwin.

Mahdi, M. (2003), Nizām al-Waqf fĩ al-Tațbìq al-Mu'ạsirir, Islamic Development Bank, Kuwait Awqaf Public Foundation, Jeddah.

Mansouri, K. (2013), "Al-Iṣlāḥ al-Idārī li mua'ssasāt qitāa al-Awqāf - Dirāsat hāalat al-Jazā'ir”, PhD thesis, University of Biskra, Algeria.

Marr, B. and Roos, G. (2005), "A strategy perspective on intellectual capital", in Marr, B. (Ed.), Perspectives on Intellectual Capital, Butterworth-Heinemann, Oxford, pp. 28-52.

Martínez-Torres, M.R. (2006), "A procedure to design a structural and measurement model of intellectual capital: an exploratory study", Information and Management, Vol. 43 No. 5, pp. 617-626.

Mesa, W. (2010), "The composition of intellectual capital in non-profit orchestras", Journal of Intellectual Capital, Vol. 11 No. 2, pp. 208-226.

Mesdour, F. (2008), "The Algerian experience in the management of endowments: history, present and future", Awqaf Magazine, pp. 1-28.

Mimouni, I. and Aouisi, A. (2018), "Hawkamat al-waqf wa 'alāqtuhā bi tațīr al-mu'assasat alwaqfiyah”, Id̄àrat al-Dirāsāt wa al-'Alāqāt al-Khārijiyah, Vol. 4 No. 1, pp. 1-136. 
Mohamad, S. and Ariff, M. (2016), "Issues in the Malaysian waqf system", CIAWM Special Edition 2013-2015, pp. 12-13.

Mohsin, M.I.A. (2010), "Revitalization of waqf administration and family waqf law", US-China Law Review, Vol. 7 No. 6, pp. 57-64.

Mohsin, M.I.A. and Muneeza, A. (2019), "Integrating waqf crowdfunding into the blockchain: a modern approach for creating a waqf market", in Oseni, U.A. and Ali, S.N. (Eds), Fintech in Islamic Finance: Theory and Practice, Routledge, Abingdon, UK, pp. 266-279.

Mouritsen, J. (1998), "Driving growth: economic value added versus intellectual capital", Management Accounting Research, Vol. 9 No. 4, pp. 461-482.

Mouritsen, J., Larsen, H.T. and Bukh, P.N. (2005), "Dealing with the knowledge economy: intellectual capital versus balanced scorecard”, Journal of Intellectual Capital, Vol. 6 No. 1, pp. 8-27.

Mustapha, R. and Abdullah, A. (2004), "Malaysia transitions toward a knowledge-based economy", Journal of Technology Studies, Vol. 30 No. 3, pp. 51-61.

Nonaka, I. (1994), “A dynamic theory of organizational knowledge creation”, Organization Science, Vol. 5 No. 1, pp. 14-37.

Obaidullah, M. and Shirazi, N.S. (2017), IRTI Islamic Social Finance Report 2017 (1438H), Jeddah.

Ordóñez de Pablos, P. (2004), "Measuring and reporting structural capital: lessons from European learning firms", Journal of Intellectual Capital, Vol. 5 No. 4, pp. 629-647.

Osbehi, A.R. (2015), "Al-Ḥimāyah al-Qānūniyah li al-Awqāf al-'Āmmah bi al-Maghrib”, paper presented at the Local Scientific Council for Employment in Tangier Asilah, June 2015, Tangier Asilah, Morocco, available at: www.bibliotdroit.com/2016/10/pdf_860.html (accessed 29 November 2018).

Qabbani, M. (2003), "Taḥawwulat 'Alāqat al-Waqf bi mu'assasat al-Mujtama' al-Madanī fĩ buldān alHilāl al-Khașī̄", in Al-Bayoumi Ghanim, I. (Ed.), Nižām al-Waqf wa al-Mujtama' al-Madanī fī alWațan al-' Árabī, Markaz Dirāsāt al-Wiḥdah al-'Arabiyyah, Beirut, Lebanon, pp. 702-725.

Ramírez, Y. and Gordillo, S. (2014), "Recognition and measurement of intellectual capital in Spanish universities", Journal of Intellectual Capital, Vol. 15 No. 1, pp. 173-188.

Ramírez, Y., Lorduy, C. and Rojas, J. (2007), "Intellectual capital management in Spanish universities", Journal of Intellectual Capital, Vol. 8 No. 4, pp. 732-748.

Ramirez, Y., Tejada, A. and Manzaneque, M. (2016), "The value of disclosing intellectual capital in Spanish universities: a new challenge of our days", Journal of Organizational Change Management, Vol. 29 No. 2, pp. 176-198.

Rashid, S.K. (2012), "Measures for the better management of awqāf”, IIUM Law Journal, Vol. 20 No. 1, pp. 1-35.

Rashid, S.K. (2018), "Potential of waqf in contemporary world", Journal of King Abdulaziz University: Islamic Economics, Vol. 31 No. 2, pp. 53-69.

Roos, G., Bainbridge, A. and Jacobsen, K. (2001), "Intellectual capital analysis as a strategic tool", Strategy and Leadership, Vol. 29 No. 4, pp. 21-26.

Roos, G. and Roos, J. (1997), "Measuring your company's intellectual performance", Long Range Planning, Vol. 30 No. 3, pp. 413-426.

Rusydiana, A.S. and Devi, A. (2018), "Elaborating cash waqf development in Indonesia using analytic network", International Journal of Islamic Business and Economics (Ijibec)), Vol. 2 No. 1, pp. 1-13.

Saiti, B., Salad, A.J. and Bulut, M. (2019), "The role of cash waqf in poverty reduction: a multi-country case study”, in Ghazali, M. Mutum, E. ,Rashid, D.S.M. and Ahmed, J.U. (Eds), Management of Shariah Compliant Businesses: Case Studies on Creation of Sustainable Value, Springer, Cham, Switzerland, pp. 21-34. 
Salamon, L.M. and Anheier, H.K. (1997), Defining the Nonprofit Sector: A Cross-National Analysis, Manchester University Press, Manchester.

Salamon, L.M. and Anheier, H.K. (1996), "The international classification of nonprofit organizations: ICNPO-Revision 1, 1996”, Working paper of Johns Hopkins Comparative Nonprofit Sector Project, No. 19., The Johns Hopkins Institute for Policy Studies, Baltimore.

Sawhill, J. and Williamson, D. (2001), "Measuring what matters in nonprofits", McKinsey Quarterly, Vol. 2, pp. 98-107.

Seleim, A. and Khalil, O. (2007), "Knowledge management and organizational performance in the Egyptian software firms", International Journal of Knowledge Management (Management), Vol. 3 No. 4, pp. 37-66.

Seleim, A.A.S. and Khalil, O.E.M. (2011), "Understanding the knowledge management-intellectual capital relationship: a two-way analysis”, Journal of Intellectual Capital, Vol. 12 No. 4, pp. 586-614.

Shih, K.-H., Chang, C.-J. and Lin, B. (2010), "Assessing knowledge creation and intellectual capital in banking industry”, Journal of Intellectual Capital, Vol. 11 No. 1, pp. 74-89.

Steinberg, R. and Gray, B.H. (1993), "The role of nonprofit enterprise' in 1993: hansmann revisited", Nonprofit and Voluntary Sector Quarterly, Vol. 22 No. 4, pp. 297-316.

Stewart, T.A. (1994), "Your company's most valuable asset: intellectual capital", Fortune, Vol. 130 No. 7, pp. 68-74.

Stewart, T. and Ruckdeschel, C. (1998), "Intellectual capital: the new wealth of organizations", Performance Improvement, Vol. 37 No. 7, pp. 56-59.

Suhaili, N.A. and Palil, M.R. (2016), "Crowdfunding: a collaborative waqf-based internet platform”, International Journal of Business, Economics and Law, Vol. 11 No. 5, pp. 41-46.

Sulaiman, M., Zakari, M.A. (2015), "Efficiency and effectiveness of waqf institutions in Malaysia: toward financial sustainability", in El-Karanshawy, H.A. et al. (Eds), Access to Finance and Human Development - Essays on Zakah, Awqaf and Microfinance, Bloomsbury Qatar Foundation, Doha, Qatar, pp. 43-53.

Sveiby, K.E. (1997), The New Organizational Wealth: Managing and Measuring Knowledge-Based Assets, Berrett-Koehler Publishers, San Francisco, CA.

Thaker, M.A.M.T., Thaker, H.M.T. and Pitchay, A.A. (2018), "Modeling crowdfunders' behavioral intention to adopt the crowdfunding-waqf model (CWM) in Malaysia", International Journal of Islamic and Middle Eastern Finance and Management, Vol. 11 No. 2, pp. 231-249.

WBG, INCEIF, and ISRA (2019), The World Bank Group, INCEIF and ISRA Report on Maximizing Social Impact through Waqf Solutions, The World Bank Group, INCEIF and ISRA, Kuala Lumpur.

Weisbrod, B.A. (2009), The Nonprofit Economy, Harvard University Press, Cambridge, MA.

Wilson, M.I. and Larson, R.S. (2002), "Nonprofit management students: Who they are and why they enroll?”, Nonprofit and Voluntary Sector Quarterly, Vol. 31 No. 2, pp. 259-270.

\section{About the authors}

Abdelkader Laallam is a PhD holder from the IIUM Institute of Islamic Banking and Finance (IIiBF), International Islamic University Malaysia (IIUM). His research interests include corporate governance, social finance, Islamic finance, Islamic economics, intellectual capital, knowledge management and technology management. Abdelkader Laallam is the corresponding author and can be contacted at: kader0991@gmail.com

Salina Kassim, PhD, is the Dean and Associate Professor at the IIiBF, IIUM. She received her PhD in Monetary Economics in 2006 from IIUM and her master's and bachelor's degrees from the USA in 1992 and 1994, respectively. Prior to becoming an academician, she has several years of working 
$\mathrm{IJIF}$

12,1

experience as a Senior Executive at the Economics and Corporate Planning Division of a commercial bank in Malaysia. She served as Adjunct Professor at the Universitas Airlangga, Surabaya, Indonesia for the period January 2019-December 2019.

Engku Rabiah Adawiah Engku Ali, PhD, is currently a professor at the IIiBF, IIUM. She obtained her LLB (first-class honours) and LLB (Shariah) (first-class honours) from the IIUM. Shortly, thereafter, she successfully completed her Masters of Comparative Laws (MCL) with distinction from the same university. She was conferred with $\mathrm{PhD}$ in Law (securities regulation) from the University of Aberdeen, the UK. She serves as a member of the Shariah advisor and consultant to several financial institutions and legal firms.

Buerhan Saiti, PhD, is an Associate Professor at the Istanbul Sabahattin Zaim University and recipient of Outstanding Young Scientists Award by Turkey Academy of Sciences (2018-2021). Previously, he was Associate/Assistant Professor and Senior Lecturer at IIUM and University Kuala Lumpur, respectively. He was awarded by the IIUM for publishing the highest number of articles in citation-indexed journals in social science category in 2017. He was named among the top 1 per cent reviewers in 2018 and 2019 by Publons (WoS).

For instructions on how to order reprints of this article, please visit our website: www.emeraldgrouppublishing.com/licensing/reprints.htm Or contact us for further details: permissions@emeraldinsight.com 